\title{
Predilection of sustainable recharge structures using morphometric parameters and decision making model in the Vaniyar sub basin, South India
}

\author{
S. Satheeshkumar ${ }^{1}$ (D) . S. Venkateswaran ${ }^{1}$
}

Received: 10 July 2018 / Accepted: 2 October 2018 / Published online: 29 October 2018

(c) The Author(s) 2018

\begin{abstract}
The morphometric parameters are depicting the hydrological reaction through geographic information systems (GIS) and geospatial techniques used for water conservation. In this area, drainage system shows a dendritic pattern occasion where the most outrageous number of streams found in the primary request and the stream arrange extended by receding in stream number. The preference criteria were chosen in the pappiredipatti watershed compared to other watersheds in the sub basin based on slope condition, rainfall, and weathered zone thickness. The highest mean bifurcation ratio is 4.9 at yercaud watershed whereas the lowest mean bifurcation ration is 1.8 in kadattur watersheds. The mean bifurcation proportion was 3.125 which demonstrate that the discharge design is influenced by auxiliary aggravations. The Elongation ratio lowest in 0.53 at kadattur and highest at KRW is 0.8 , form factor esteems were 0.67 and 0.1 .92 which specify stretched state of the bowl having a compliment high point of the stream for longer spans. Flowing streams of the prolonged basin are less demanding to oversee for accommodating to deciding the impact of the catchment territory on hydrological valuation. In the pappiredipatti watershed was chosen preference criteria of recharge structures, number of structures 8,12 , and 30 of check dams were built on 1st, 2nd, 3rd order stream individually. Two permeation lakes were developed nearer to 3rd order stream. Artificial recharge structures in 1st order are lower than in 2nd order, according to the morphometric investigation, the 2nd and 3rd order stream are described by high penetrable, high infiltration limit and low help, which is conducive for the recharge. The accompanying observations made while settling on the sort and plan of maintainability structures for the proper location.
\end{abstract}

Keywords Morphometric parameters $\cdot$ Decision support model $\cdot$ Bifurcation ratio $\cdot$ Stream orders and watershed

\section{Introduction}

The estimation of the earth's surface, shape of view and measurement of the zone area of its landforms that are characterising as morphometry. Fluvial morphometry have one of the comprises the consideration of linear, areal and relief part of a fluvial system of drainage indicated that origin the landforms and its characteristics. The linear viewpoint bargains with the various stream orders, stream numbers, stream lengths of sections and other connections among them and it is to be valuable to reasonable location. The areal aspect is important includes the analysis of perimeters,

S. Satheeshkumar

aiswarkumar2781@gmail.com

1 Hydrogeology Laboratory, Department of Geology, Periyar University, Salem, Tamil Nadu 636011, India shape, area, allometric growth, stream frequency, drainage density and drainage texture of the watershed development and management by water conservation and soil prevention. The relief aspect incorporates ratios, average slope, and dissection index, which have indicated as one of flow of rainfall and water flow direction. Morphometric parameter analysis is alluded as the quantifiable assessment of border attributes of the earth's surface and some landform part. This has great widely recognized method in basin examination, as morphometry shape a perfect areal aspect of understanding and investigation of fluvial started landforms where they show and the case of exposed frameworks of process. The creation of the stream order of a drainage basin in interactive with stream arranges seepage thickness, bifurcation ratio and stream length ratio of the sub basin. It consolidates quantifiable investigation of the different parts, for instance, stream portions, length, parameters, watershed zone, elevation, volume, slant, profiles of the arrive which illustrates 
the thought of progression (Horton 1932, 1945). These present-day approaches have quantifiable of the drainage basin contributions by Horton (1945), the principal innovator in this field. A geometric relationship between the quantities of stream sections in progressive stream orders of Horton's law of stream lengths. The basin territories showed that the mean sub basin territory of progressive requested river shaped a direct association once diagrammed. Horton's laws were therefore altered, then created by a few geomorphologists, furthermost outstandingly by Morisawa (1985), Strahler (1953), Scheidegger (1965), Schumm (1956a, b), Clarke (1966), Gregory and Walling (1973) and Shreve (1967). In this manner, various books through Keller and Pinter (1996), Bloom (1979), have additionally, proliferated the morphometric investigation. Stream profile examination and stream slope list by Hack (1960) have another point of reference in the morphometric investigation. Numerous laborers are utilized the standards founds to quantitatively examine the drainage basin of the Vaniyar sub basin as an instrument for scene investigation.

Morphometry parameter used as quantifiable estimations an observation apparatuses to make inductions around specific ordinary aimed at a region through structural movement. Geomorphic records like hypsometric essential, watershed asymmetry, stream length, slope, foreground of mountain sinuosity index uses an admeasurement of the activating subsurface. Landforms are fabricated by an agency of erosional and depositional forms, the geometry of which is controlled by the measures that appearance them. Morphometric examinations crave admiration of beeline highlights, the bend of approach acclivity and the accidental arena abruptness of the drainage basin (Nautiyal 1994). The morphometric assay for a typical has been able through estimations of straight, aerial aspect, allotment of the basin and the slope ability pointed out by (Nag and Chakraborty 2003). The basin of watershed for geomorphic attributes has in quite some time been recognized to be vital records of surface measures. These parameters have been utilized as a part of different investigations of geomorphology and surface-water hydrology, for example, flow attributes, dregs yield, and advancement of bowl morphology (Ogunkoya et al. 1984; Jenson 1991). By counting bowl qualities, for example, height and primary channel inclination, expectations of stream release were enhanced in contrast with utilizing just seepage terrain and precipitation (Jolly 1982; Aryadike and Phil-Eze 1989; Breilinger et al. 1993). Landscape portrayal turned into a critical part of displaying surface procedures (Nogami 1995). The point by point investigation of morphometric of linear, areal, aspect and morphological character demonstrate the part of the neotectonics in forming the drainage sub basin. Landsat images are utilized by way of a helpful apparatus in morphometric investigation using geographic information systems (GIS) and remote detecting strategies. Numerous specialists have completed morphometric investigation utilizing innovative approach. In this case, Digital Elevation Model (DEM) and Shuttle Radar Topography Mission (SRTM) data utilized for the drainage basin investigation. The objective of the study is to select suitable recharge structures using DMM and existing recharge structures their efficient assessment.

\section{Study area}

The Vaniyar sub basin is $1030 \mathrm{~km}^{2}$ and situated between $78^{\circ} 20^{\prime} 25^{\prime \prime}$ and $78^{\circ} 40^{\prime} 0^{\prime \prime} \mathrm{E}$ longitudes $11^{\circ} 48^{\prime} 30^{\prime \prime}$ and $12^{\circ} 07^{\prime} 30^{\prime \prime} \mathrm{N}$ Latitude. The Vaniyar River is flowing towards the north east of this sub basin (Fig. 1). Perceiving and inspecting rainfall is crucially necessary as the source of surplus water. The accessibility of supply water, one of the tall essentials for groundwater revive, are essentially evaluated as far as non-conferred excess monsoon runoff, which according to display water valuable asset improvement situation is going unutilized. This module can be evaluated with the help of analyzing the precipitation design, and its recurrence. The varieties in precipitation design in interval as appropriate as its significance in connection toward the possibility for reviving to groundwater supplies can be respected for surveying the excess accessibility of surplus water.

\section{Methods}

Drainage basin parameter are extracted the network of the basin and allotting the stream order from a distributed Survey of India (SOI) topographic guide and after georeferenced satellite information for a substantial region in Fig. 2. A set of the extraction procedures has been used for assessing the hydromorphometric parameters of a sub basin. Extraction of the river basin, watershed limit and extraction of stream shape of the Vaniyar sub basin utilizing ASTER data in combination with geocoded standard false shading composite remote detecting satellite information (Landsat ETM) and georeferenced SOI toposheets having 1:250,000 scale utilized by ArcGIS- software. The stream systems extracted in sub basin for predicted to the provincial plan water resource management.

Various watersheds in the Vaniyar river basin are consequently separated after the ASTER information by a spatial determination of $30 \mathrm{~m}$ utilized by geo-referenced Survey of India. Drainage network extractions are important to quantify drainage system. The drainage pattern in Vaniyar sub basin is dendritic system (Fig. 3). The yield of this strategy is a reason for making a stream 

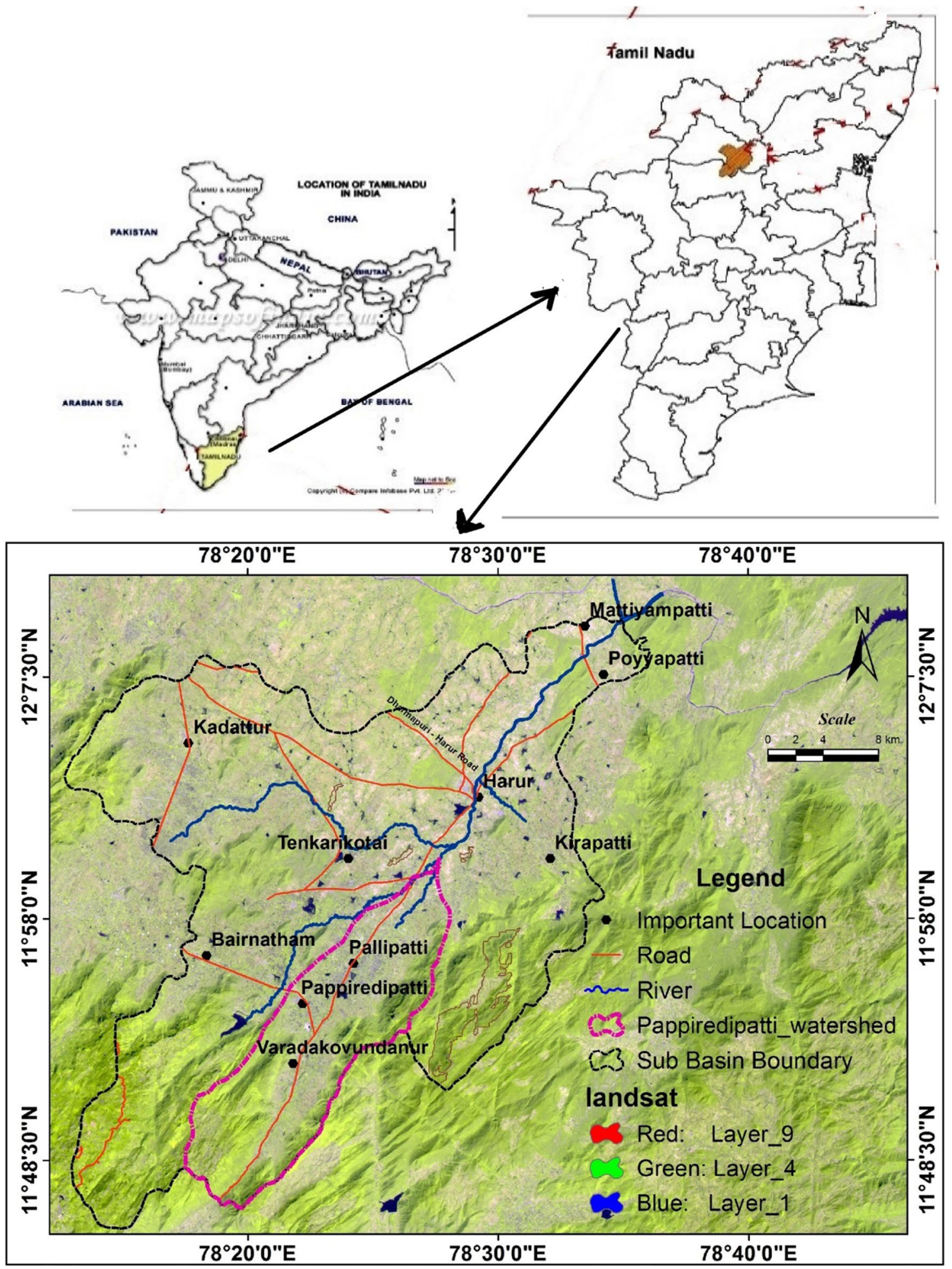

Fig. 1 Location of the study area

order arrange in light of Strahler (1964). As fact out over that Strahler's a first-developed the stream order as arrangement of grouping assigns a portion without any tributaries. In addition, two first-arrange where stream portions go along with, they frame a moment arrange stream portion. 


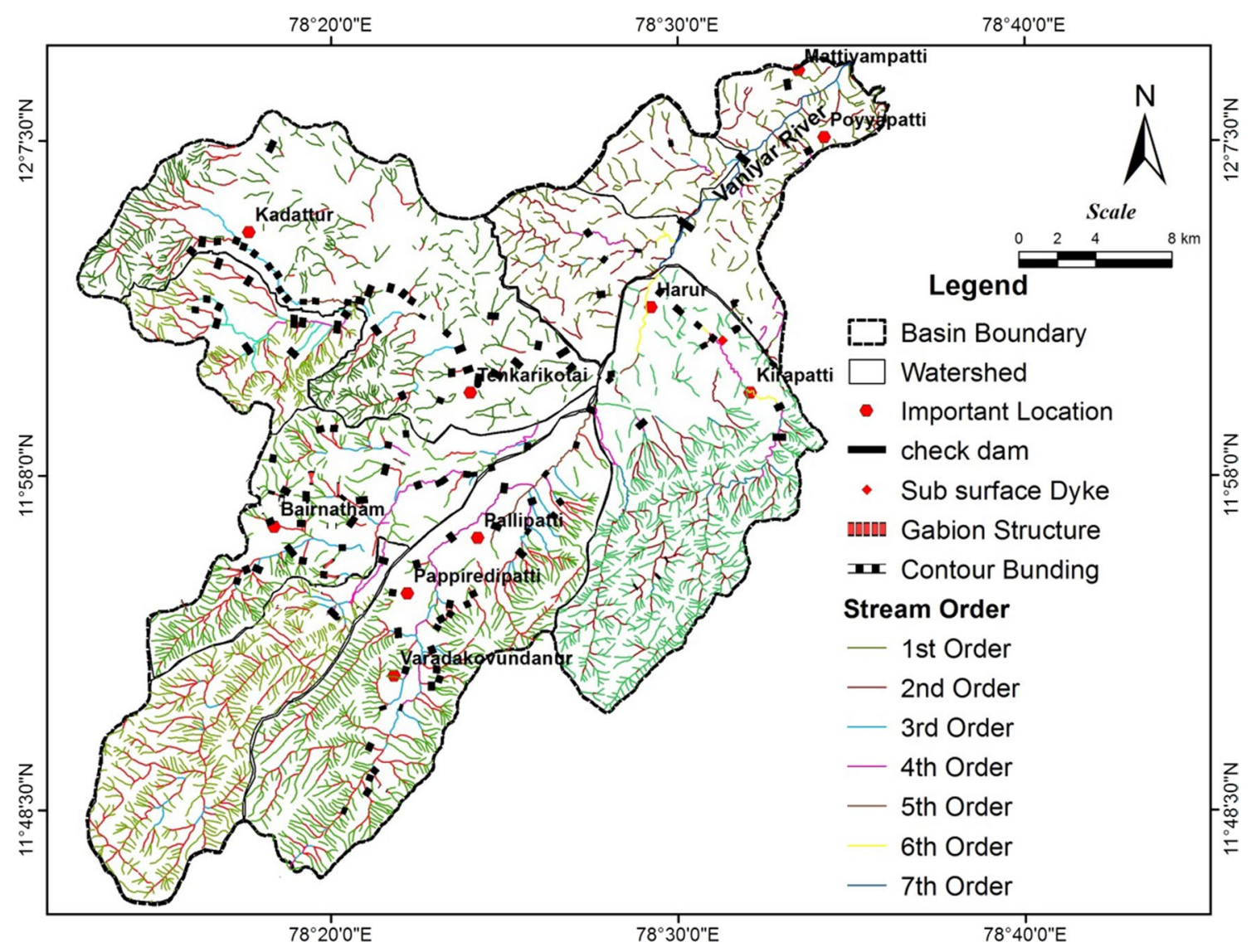

Fig. 2 Stream order with recharge structures in the study area

Fig. 3 Variation of the stream order versus total length of stream

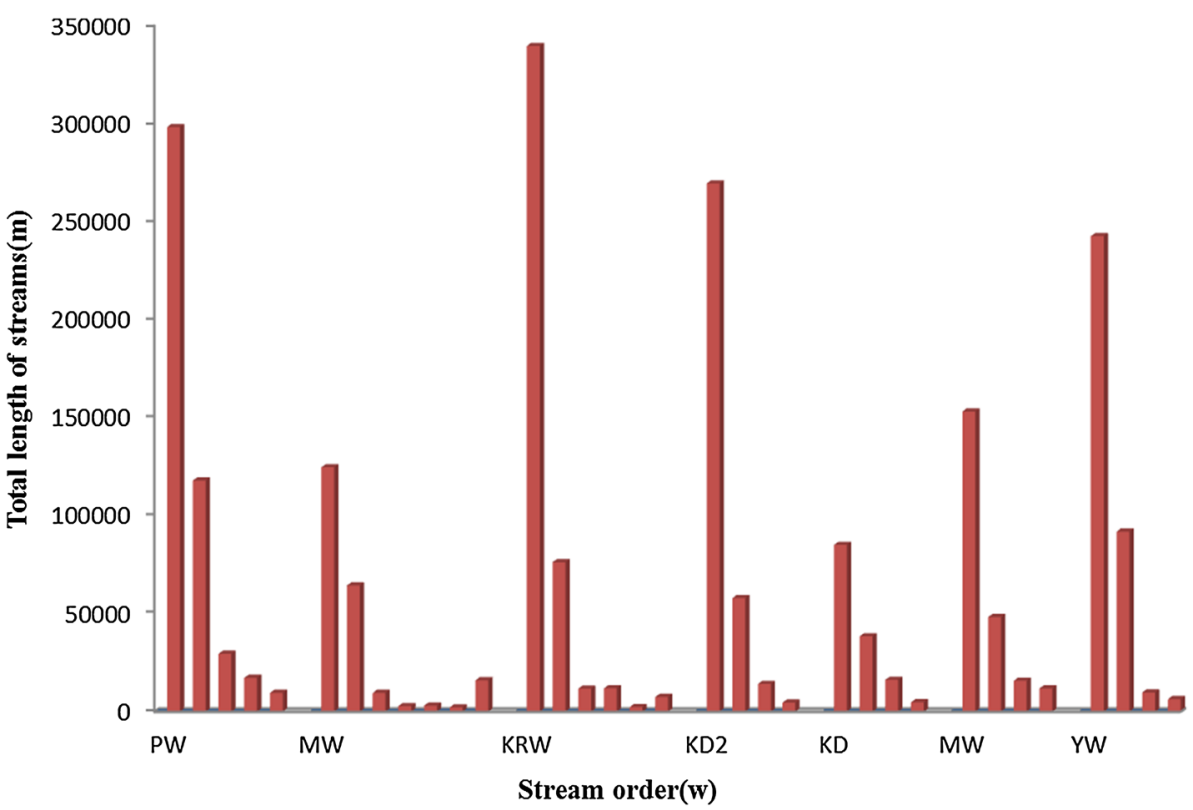


Table 1 Morphometric parameters

\begin{tabular}{lll}
\hline S. no. & Parameters & Formulae with references \\
\hline 1 & Stream order $\left(N_{\mathrm{u}}\right)$ & Hierarchical rank (Strahler's 1964) \\
2 & Stream length $\left(L_{\mathrm{u}}\right)$ & Length of the stream (Horton 1945) \\
3 & Mean stream length $\left(L_{\mathrm{sm}}\right)$ & $L_{\mathrm{sm}}=L_{\mathrm{u}} / N_{\mathrm{u}}($ Strahler 1964) \\
4 & Stream length ratio $\left(R_{\mathrm{L}}\right)$ & $R_{\mathrm{L}}=L_{\mathrm{u}} /\left(L_{\mathrm{u}}-1\right)$ (Horton 1945) \\
5 & Bifurcation ration $\left(R_{\mathrm{b}}\right)$ & $\left(R_{\mathrm{b}}\right)=N_{\mathrm{u}} / N_{\mathrm{u}}+1$ (Schumm 1956a, b) \\
6 & Mean bifurcation ratio & Bifurcation ratios of all order $($ Strahler 1957) \\
7 & Form factor $\left(F_{\mathrm{f}}\right)$ & $F_{\mathrm{f}}=A / L^{2}$ (Horton 1932) \\
8 & Circularity index $(C)$ & $C=4 \pi A / \rho^{2}$ (Leopold et al. 1964) \\
9 & Lemniscate method $(k)$ & $K=L^{2} / 4 A$ \\
10 & Elongation ratio $\left(R_{\mathrm{e}}\right)$ & $R_{\mathrm{e}}=D / L=1.128 \sqrt{ } A / L($ Schumm 1956a, b) \\
11 & Stoddart's elipticity $(E)$ & $E=\Pi L^{2} / 4 A$ (Stoddart's 1965) \\
12 & Stream frequency $\left(F_{\mathrm{s}}\right)$ & $F_{\mathrm{s}}=N_{\mathrm{u}} / A$ (Horton 1945) \\
13 & Drainage texture $(T)$ & $T=D_{\mathrm{d}} \times F_{\mathrm{s}}($ Smith 1950) \\
14 & Drainage density $\left(D_{\mathrm{d}}\right)$ & $D_{\mathrm{d}}=L_{\mathrm{u}} / A$ (Horton $(1945)$ \\
\hline
\end{tabular}

\section{Morphometric parameters}

In the present study, deals the characteristic morphometric of watershed in the sub basin has been done as direct morphometric parameters like as stream number, bifurcation proportion, stream order, stream length, length ratio, a real parameter [drainage texture, basin region, drainage density, border, stream, frequency length, and] and relief parameters [aspect, rise and slope] utilizing scientific formulae have as shown in Table 1.

\section{Stream number, stream orders and drainage pattern}

There are many contributing streams, which are combined in the watershed of the Vaniyar sub basin is a dendritic drainage, which appears which form into the branches and trunk of the trees and demonstrates the regularity and consistency in hydrological properties. The Vaniyar sub basin of the total drainage area is of the $1030 \mathrm{~km}^{2}$ out of $178 \mathrm{~km}^{2}$ and the second major contribution to water resource development in the pappiredipatti watershed. In the present investigation, the position of the stream has been finalized in view of a technique planned (Strahler 1964) after the digitized streams from toposheet, Google earth and DEM. The stream order attributes shown in Table 2.

The stream order begins with first in the watershed to a 5 th order stream of the basin. The most stream-arrange recurrence is seen if there should arise an occurrence of 1st order and after that 2 nd order. It has seen lessening in the stream recurrence as stream order increments and bad habits. The primary order and as the stream order increases were found in sub basin, there is a decline in stream number. As indicated by Strahler (1964), when two flows of various requests join, neither increase altogether. For instance, instants arrange stream joins a 3 rd order; the 2 nd order basically closes by streaming its substance into the 3rd order, which at that point keeps up its place in the pecking order. It suggests that the pappiredipatti watershed has the most third order stream joins to shape. Stream include each stream order of the pappiredipatti watershed was processed through ArcGIS techniques (Horton 1945). The quantity of streams continuously diminishes as the stream order expands; the assortment in stream direction and the span of the river sub basin to an incredible degree depend upon physiographical, geomorphological of the range. In the sub basin, the maximum $79 \%$ of 1 st order observed in $\mathrm{KR}$ watershed, which is compared to second, third order and so on. An aggregate of 906 streamlines, order including the pappiredipatti is one of the main watersheds in the sub basin were perceived, at which $52.98 \%$ (480) was a piece of the principal stream order, $38.07 \%$ (345) was second-arrange stream and the third-arrange stream contained $5.18 \%$ (47) and remaining 4 th and 5 th order stream $3.58 \%$. This adjustment in stream orders shows streams spilling out of high height to low elevation with diminishing indecent variety of lithological attributes.

\section{Bifurcation ratio}

The quantity of the stream sections of offered appeal to the number of portions of term bifurcation proportion might be characterized as the proportion of the following higher order as per Schumm (1956a, b). It is not necessary dimension property and demonstrates the level of coordination attractive between surges of different needs. In light of standard strategy of bifurcation proportion investigation (Strahler 1964), the estimations of bifurcation ratio for the pappiredipatti watershed fluctuated from 1.2 to 7.3 demonstrating the observed bifurcation proportion is not the similar as of one request to its subsequent application pointed out by 
Table 2 Linear aspect of the Vaniyar sub basin

\begin{tabular}{|c|c|c|c|c|c|c|c|}
\hline & $\begin{array}{l}\text { Stream order } \\
(w)\end{array}$ & $\begin{array}{l}\text { Number of } \\
\text { streams }\left(N_{\mathrm{u}}\right)\end{array}$ & $\begin{array}{l}\text { Bifurcation } \\
\text { ratio }\left(R_{\mathrm{bF}}\right)\end{array}$ & $\begin{array}{l}\text { Mean Bifurcation } \\
\text { ratio }\left(R_{\mathrm{bm}}\right)\end{array}$ & $\begin{array}{l}\text { Total length of } \\
\text { streams }(m)\end{array}$ & $\begin{array}{l}\text { Mean length of } \\
\text { streams }(m)\end{array}$ & Length ratio $\left(R_{\mathrm{L}}\right)$ \\
\hline \multirow[t]{5}{*}{ PW } & 1 & 480 & & 3.125 & 298,226 & $94,550.4$ & \\
\hline & 2 & 345 & 1.4 & & 118,014 & & 2.53 \\
\hline & 3 & 47 & 7.3 & & 29,596 & & 3.99 \\
\hline & 4 & 18 & 2.6 & & 17,285 & & 1.71 \\
\hline & 5 & 16 & 1.2 & & 9631 & & 1.80 \\
\hline \multirow[t]{7}{*}{ MW } & 1 & 246 & & 4.323 & 124,805 & $31,885.7$ & \\
\hline & 2 & 134 & 1.8 & & 64,495 & & 1.93 \\
\hline & 3 & 15 & 8.9 & & 9622 & & 6.70 \\
\hline & 4 & 5 & 3.0 & & 2889 & & 3.33 \\
\hline & 5 & 6 & 8.3 & & 3121 & & 0.92 \\
\hline & 6 & 5 & 1.2 & & 2199 & & 1.41 \\
\hline & 7 & 7 & 7.1 & & 16,069 & & 0.13 \\
\hline \multirow[t]{6}{*}{ KRW } & 1 & 817 & & 1.8 & 339,604 & $74,942.3$ & \\
\hline & 2 & 180 & 4.5 & & 76,344 & & 4.44 \\
\hline & 3 & 18 & 1.0 & & 11,793 & & 6.47 \\
\hline & 4 & 11 & 1.6 & & 11,944 & & 0.98 \\
\hline & 5 & 4 & 2.7 & & 2374 & & 5.03 \\
\hline & 6 & 4 & 1.0 & & 7595 & & 0.31 \\
\hline \multirow[t]{4}{*}{ KD2 } & 1 & 573 & & 2.275 & 269,459 & $86,595.25$ & \\
\hline & 2 & 95 & 6.0 & & 58,009 & & 4.64 \\
\hline & 3 & 6 & 1.6 & & 14,236 & & 4.07 \\
\hline & 4 & 4 & 1.5 & & 4677 & & 3.04 \\
\hline \multirow[t]{4}{*}{$\mathrm{KD}$} & 1 & 206 & & 2.237 & 85,151 & $36,195.75$ & \\
\hline & 2 & 63 & 3.2 & & 38,497 & & 2.211 \\
\hline & 3 & 18 & 3.5 & & 16,278 & & 2.364 \\
\hline & 4 & 8 & 2.25 & & 4857 & & 3.35 \\
\hline \multirow[t]{4}{*}{ MOW } & 1 & 282 & & 2.575 & 153,043 & $57,263.25$ & \\
\hline & 2 & 98 & 2.9 & & 48,300 & & 3.16 \\
\hline & 3 & 20 & 4.9 & & 15,818 & & 3.05 \\
\hline & 4 & 8 & 2.5 & & 11,892 & & 1.33 \\
\hline \multirow[t]{4}{*}{ YW } & 1 & 543 & & 4.9225 & 242,567 & 87,694 & \\
\hline & 2 & 274 & 1.99 & & 91,935 & & 2.63 \\
\hline & 3 & 20 & 13.7 & & 9853 & & 9.33 \\
\hline & 4 & 5 & 4 & & 6421 & & 1.53 \\
\hline
\end{tabular}

Verstappen (1983). The bifurcation ratio of mean low value is 1.8 at KR watershed and high 4.9 at yercaud watershed. The mean bifurcation ratios vary from about 1.8 in flat category rather values range between 3.12 and 4.9 developed over the hilly regions (Singh and Ojha 1984). The mean bifurcation ratio (1.325) demonstrates that basin has not been influenced by basic unsettling influences.

\section{Linear regression model}

Linear Regression Model (LRM) is used to validate the length and frequency of stream in the area. A Point plot with convex hulls indicated stream length of the watershed in the area shown in Fig. 4. Basically, upper sub basin length ratio low compared to middle and lower watershed. Length ratio $<2$ represent to construct to small check dam, whereas $>2$ represent to construct the major check dam. The kernel density is estimated in regard to a smooth estimator of the frequency distribution as shown in Fig. 5 Frequency with kernel density. Low to high indicated for application of choosing quantity based check dam to construct in the suitable place with respect to the hydrogeological setting of the area. The linear fit of RMA Regression accustomed perceive that among the most important major and minor check dam variables area unit associated with the variable quantity, and to explore the 


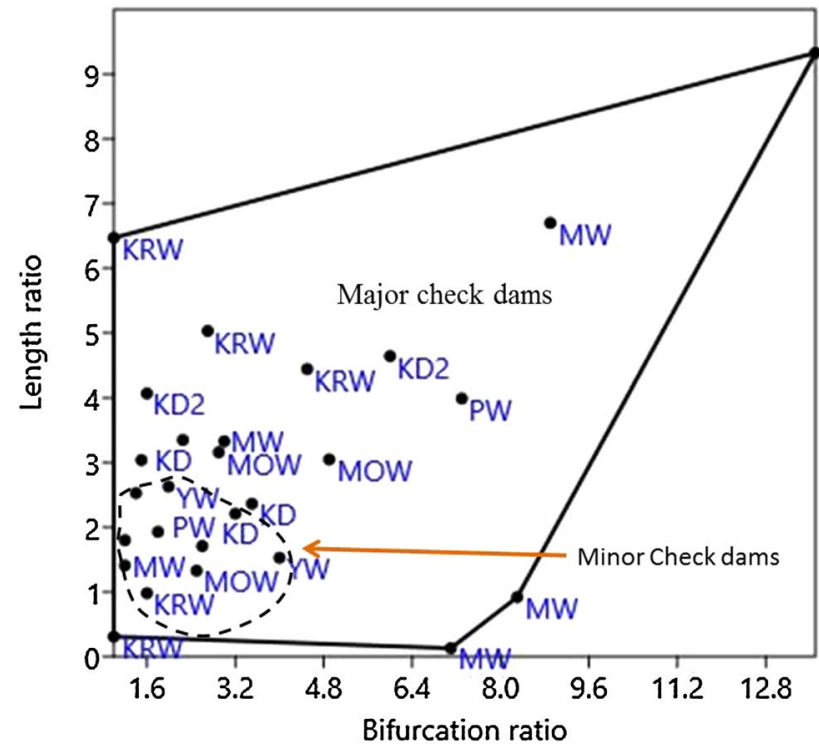

Fig. 4 Check dam suitability by Point plot with convex hulls

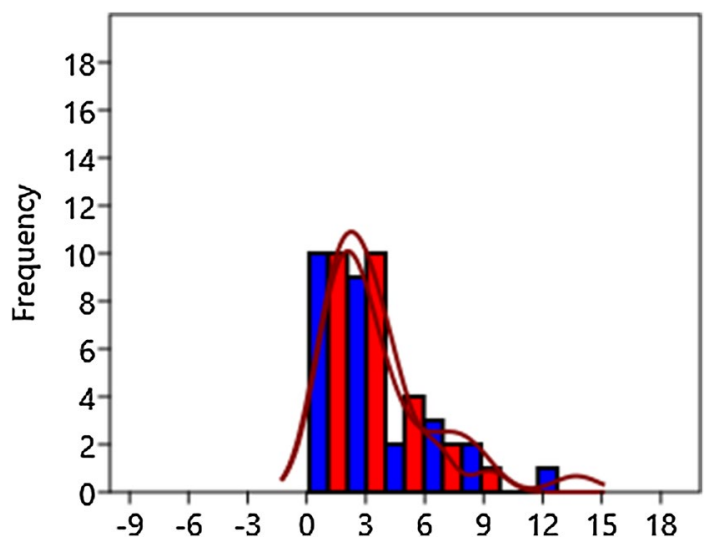

Fig. 5 Frequency with kernel density

styles of these relationships for site selection to sustainable water resource development. RMA Regression of linear fit between bifurcation ratio-length ratio of Slope $a$ : 0.76617, 95\% bootstrapped confidence intervals $(N=1999)$ : Slope a: $(0.5686,2.4444)$ as shown in Fig. 6 in Correlation: $r: 0.50082$ is positively indicated, $r^{2}: 0.25082, t: 2.8931$. RMA Regression of bifurcation ratio versus length ratio shown in Table 3. The highest ratio is 13.7 in the yercaud watershed and lowest value observed in molayanur watersheds.

The pappiredipatti watershed (PW) are in residual values closer to zero with positively and negatively and KR watershed, MW watershed beyond from it, Residual versus Bifurcation ratio as shown in Fig. 7. The high-frequency values are closer to residual values to zero and their maximum values are 14 Frequency versus residual as shown in Fig. 8.

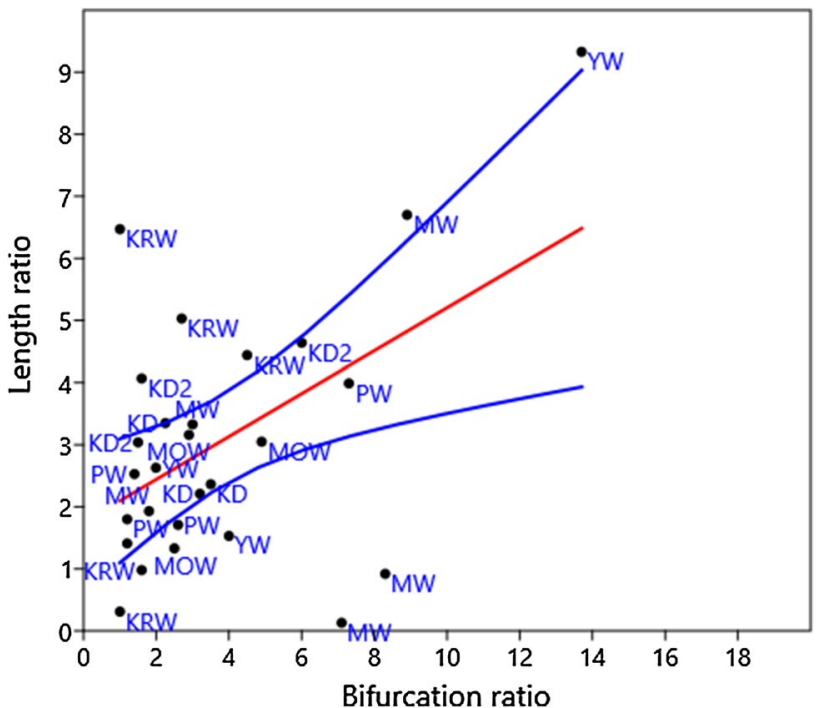

Fig. 6 Linear fit of RMA Regression of Bifurcation ratio versus Length ratio

Table 3 RMA regression: bifurcation ratio-length ratio

\begin{tabular}{|c|c|c|c|c|}
\hline Watershed & Bifurcation ratio & Length ratio & Regress. & Residual \\
\hline \multirow[t]{4}{*}{ PW } & 1.4 & 2.53 & 1.0726 & 1.4574 \\
\hline & 7.3 & 3.99 & 5.593 & -1.603 \\
\hline & 2.6 & 1.71 & 1.992 & -0.28204 \\
\hline & 1.2 & 1.8 & 0.9194 & 0.8806 \\
\hline \multirow[t]{6}{*}{ MW } & 1.8 & 1.93 & 1.3791 & 0.5509 \\
\hline & 8.9 & 6.7 & 6.8189 & -0.11891 \\
\hline & 3 & 3.33 & 2.2985 & 1.0315 \\
\hline & 8.3 & 0.92 & 6.3592 & -5.4392 \\
\hline & 1.2 & 1.41 & 0.9194 & 0.4906 \\
\hline & 7.1 & 0.13 & 5.4398 & -5.3098 \\
\hline \multirow[t]{5}{*}{ KRW } & 4.5 & 4.44 & 3.4478 & 0.99224 \\
\hline & 1 & 6.47 & 0.76617 & 5.7038 \\
\hline & 1.6 & 0.98 & 1.2259 & -0.24587 \\
\hline & 2.7 & 5.03 & 2.0687 & 2.9613 \\
\hline & 1 & 0.31 & 0.76617 & -0.45617 \\
\hline \multirow[t]{3}{*}{$\mathrm{KD} 2$} & 6 & 4.64 & 4.597 & 0.042985 \\
\hline & 1.6 & 4.07 & 1.2259 & 2.8441 \\
\hline & 1.5 & 3.04 & 1.1493 & 1.8907 \\
\hline \multirow[t]{3}{*}{$\mathrm{KD}$} & 3.2 & 2.211 & 2.4517 & -0.24074 \\
\hline & 3.5 & 2.364 & 2.6816 & -0.31759 \\
\hline & 2.25 & 3.35 & 1.7239 & 1.6261 \\
\hline \multirow[t]{3}{*}{ MOW } & 2.9 & 3.16 & 2.2219 & 0.93811 \\
\hline & 4.9 & 3.05 & 3.7542 & -0.70423 \\
\hline & 2.5 & 1.33 & 1.9154 & -0.58542 \\
\hline \multirow[t]{3}{*}{ YW } & 1.99 & 2.63 & 1.5247 & 1.1053 \\
\hline & 13.7 & 9.33 & 10.497 & -1.1665 \\
\hline & 4 & 1.53 & 3.0647 & -1.5347 \\
\hline
\end{tabular}




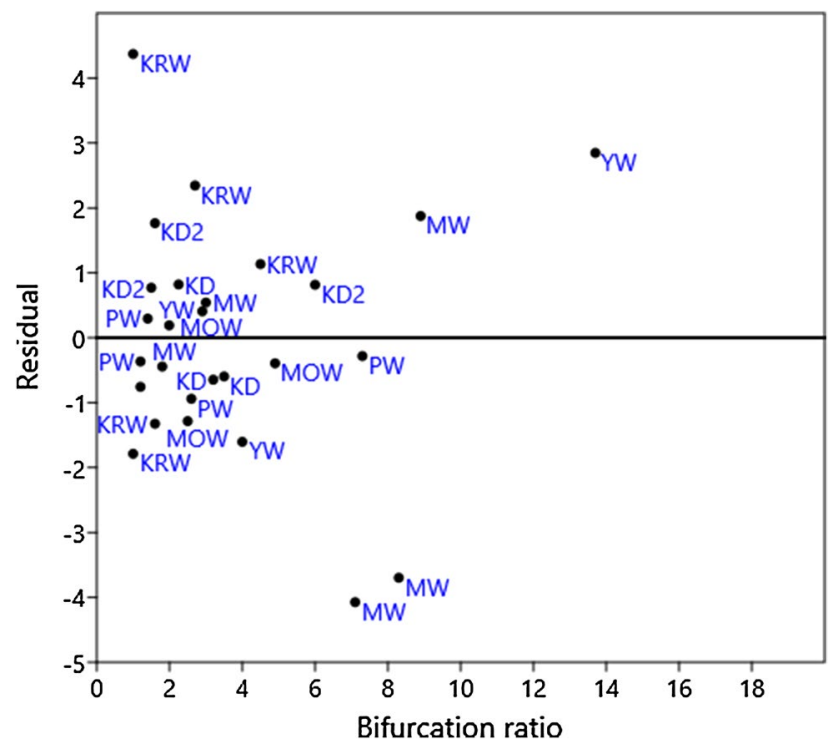

Fig. 7 Residual versus Bifurcation ratio

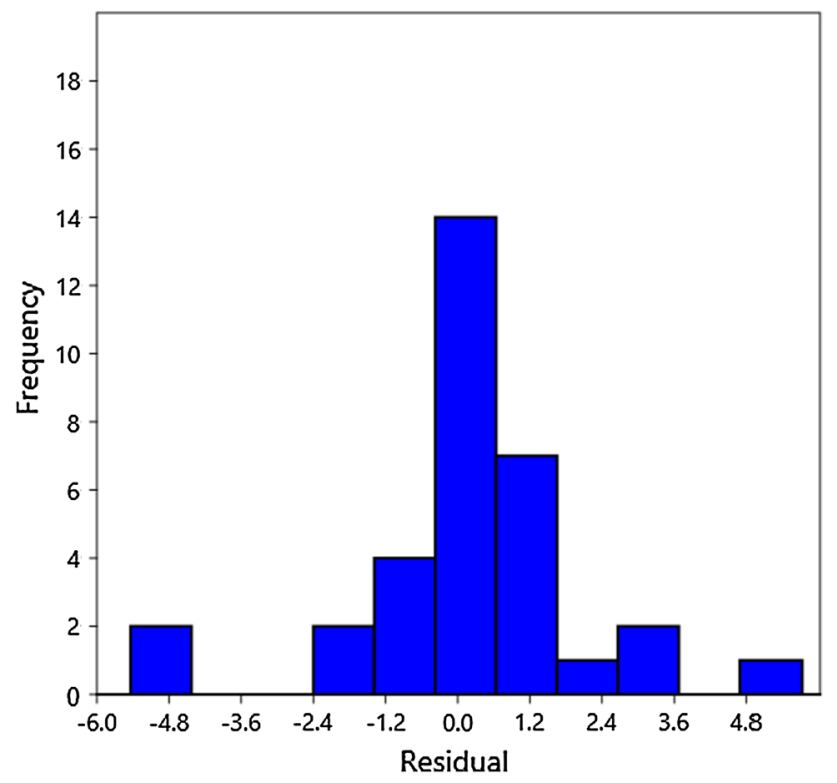

Fig. 8 Frequency versus residual

\section{Stream length ratio and stream length}

The different stream orders of values such as mean length, total length and the ratio of the Vaniyar sub basin are shown in Table 4. The sub basin explored those characteristic using geospatial on the basis of the law explained by Horton (1945) for the stream length and a stream length ratio. The pappiredipatti watershed is $472 \mathrm{~km}$ of total length of streams; out of which the first-order stream $298.22 \mathrm{~km}$ $(63.08 \%)$, second-order stream $118.01 \mathrm{~km} \mathrm{(118.01 \% )} \mathrm{and}$ third-order stream $29.59(6.25 \%)$ and 4 th order $17.28 \mathrm{~km}$ and 5 th order $9.63 \mathrm{~km}$ order stream contribute $5.68 \%$ of total length, respectively. The accumulative stream length is greater in 1st order streams and decreases as the stream adjustment increases. It is one of acutely identified. The mean spread of the breadth of the stream is $0.52 \mathrm{~km}$ in the case area. The steam length arrangement assorted from 0.002 to 7.77 , shows a change in each beck order. This change ability is attributed to irregularity in abruptness and topography conditions, (Vittala et al. 2004) in the drainage of stream of the pappiredipatti watershed.

\section{Stream frequency, drainage texture, and drainage density}

The aggregate sum of stream portions of actual desires per unit area is the stream frequency (Horton 1932) and relies upon the rock categories of the basin and mirrors the surface of the drainage link. Pappiredipatti watershed is $0.52 \mathrm{~km} /$ $\mathrm{km}^{2}$ of stream frequency showing the nearness of a porous subsurface material. Drainage density is a measure of the aggregate stream length in aggregate region (Strahler 1964). The Vaniyar river basin of the drainage density is ranging between 1.54-0.32. The investigation area of the drainage density is $0.89 \mathrm{~km} / \mathrm{km}^{2}$, which reveals that the density of drainage prompts low spillover, the coarse drainage texture, the low erosional capability of the sub basin range, and the closeness of dividing of river channels. The low density of drainage of sub basin indicates an exceptionally safe porous zone with vegetal cover and low help in the watershed for agriculture development. The drainage texture of the basin is 0.06 which proposes that it basically relies on various regular factors through atmosphere, precipitation, vegetation, rock, soil type, Temperature, their infiltration capacity in closer recharge site and relief aspect of the river sub basin.

\section{Elongation ratio and circularity index}

Elongation proportion is the proportion between the breadth of the hover of an indistinguishable range from the dendritic drainage of the sub basin (Schumm 1956a, b) and the most extreme distance. It has a measure of the state of the stream basin and it relies upon the atmosphere and geologic sorts. The pappiredipatti watershed of elongation ratio is 0.785 which proposes that the bowl has a place with the prolonged shape (Strahler 1964). Miller points out (1953) characterized dimensionless circularity ratio as the proportion of the zone to the range of circle having an indistinguishable edge from the sub basin. A circularity ratio of the watershed is 8.35 which shows emphatically stretched and exceedingly penetrable homogenous geologic character of rock materials. The Low estimation shows the youthful phases of the life cycle of the 
Table 4 Areal aspect of the Vaniyar sub basin

\begin{tabular}{|c|c|c|c|c|c|c|c|c|}
\hline S. no. & Areal aspect & PW & MW & KRW & $\mathrm{KD} 2$ & $\mathrm{KD}$ & MOW & $\mathrm{YW}^{-}$ \\
\hline 1 & Watershed area $\left(\mathrm{km}^{2}\right)$ & 184.6 & 108.67 & 176.22 & 218.18 & 57.80 & 154.46 & 112.1 \\
\hline 2 & Perimeter $(\mathrm{km})$ & 69.40 & 69.51 & 61.21 & 87 & 43.25 & 75.47 & 59.99 \\
\hline 3 & Length (km) & 68.88 & 35.07 & 22.90 & 14.44 & 34.63 & 44.96 & 22.31 \\
\hline 4 & Form factor & 0.67 & 0.77 & 1.92 & 3.77 & 0.41 & 0.85 & 1.25 \\
\hline 5 & Elongation ratio & 0.51 & 0.62 & 0.86 & 1.15 & 0.53 & 0.60 & 0.78 \\
\hline 6 & Lemniscate method & 2.54 & 1.69 & 0.87 & 0.49 & 2.27 & 1.80 & 1.05 \\
\hline 7 & Elipticity index & 7.96 & 5.28 & 2.70 & 1.53 & 7.15 & 5.68 & 1.65 \\
\hline 8 & Circularity index & 1.23 & 0.95 & 1.36 & 1.06 & 1.10 & 1.03 & 1.10 \\
\hline 9 & Drainage density $(\mathrm{km})$ & 0.70 & 1.54 & 0.58 & 0.32 & 0.64 & 0.96 & 0.61 \\
\hline
\end{tabular}

tributaries in the pappiredipatti watershed. Elongation proportion is impacted by the length and recurrence of the streams, lithology of area, recharge structures, land use/ land cover changes, climate condition, relief and aspect, and slope.

\section{Form factor}

The high esteem of form factor and circularity index showed more circular the shape of the basin. These factors may have characterized as the proportion of the watershed region to the square of the length as indicated by Horton (1932). The form factor shows the stream power of a basin in a characterized region. The form factor esteem is ( $<0.78$, Kumar et al. 2017) for the non-round basin. The perceived form factor estimation of the sub basin is 0.67 proposing that the state is prolonged. The lengthened with low-form factor shows that the basin has a compliment pinnacle of the stream for the longer term (Christopher 2010). Flood streams of the stretched basin are less demanding to oversee than those of the round bowl. The estimation of the form factor, the extended to be the sub basin basin though high-shape factors encounter bigger pinnacle streams of shorter length.

\section{Relief (R)}

The elevation distinction among the most noteworthy and least focuses on the valley floor of a sub basin is as the total relief. The relief ratio ( $\mathrm{Rh}$ ) of most extreme help to level separation beside the length measurement of the sub basin parallel to the chief drainage link is named as a relief ratio. It measures the general steepness of a drainage sub basin and is a pointer of the force of the disintegration forms process on the slope (Schumm 1956a, b). The most astounding comparative help is ascertained as $4368 \mathrm{~m}$, whereas the least esteem shown as $1319 \mathrm{~m}$ (Fig. 9). The little relief shows a northern piece of the watershed is level to delicate incline type.

\section{Relief ratio}

The ratio between the entire basin the lowest and accomplished credibility of a basin and the longest ambit of the river basin parallel to the drainage line (Schumm 1956a, b). That has a dimensionless top-period ratio and permits comparison in the comfort of basin regardless of the variance in topography. Relief ratio is same as the properly angled triangle and is equal to the perspective of the slope with respect to the horizontal. This is often degree the in general steepness of a drainage sub basin is a marker of the profundity of abrasion strategies (Strahler 1964). Running on the slope of the basin are comfort ratio usually surges with reducing drainage location and length of a given dendritic basin (Gottschalk 1964). The drainage basins of the relief ratio have varied between the values of 7.70 to 30.26 with the average of 2.16 (Table 5).

A basin suggests the low relief ratio. The kadattur side relief order foundation shows high remedy ratio than pappiredipatti watershed of the sub basins. Within the area basins of low remedy ration because of high probability erosion of the lithology kind in the pappiredipatti watershed. Higher values of the remedy ratio inside the kadattur may be using the occurrence of tremendously hardy rocks of primary. The excessive values of relief imply steep slope and high remedy controls the charge of conversion of the capacity of water draining in the basin. The surplus water is commonly faster in steeper basins, creating peaked sub basin releases and extra erosive strength.

\section{Ruggedness range}

Ruggedness variations are due to the making of most basin improvement and drainage density (DD) and it generally, combines slope with its period (Strahler 1968). In the sub basins, the ruggedness quantity varies from 139.84 for KD2 with low sloping vicinity to 856.24 for MW having better relief with the sluggish exchange in the slope of a uniform nature. The basin suggests a low value of ruggedness range at the kadattur, a moderate value

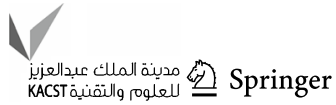




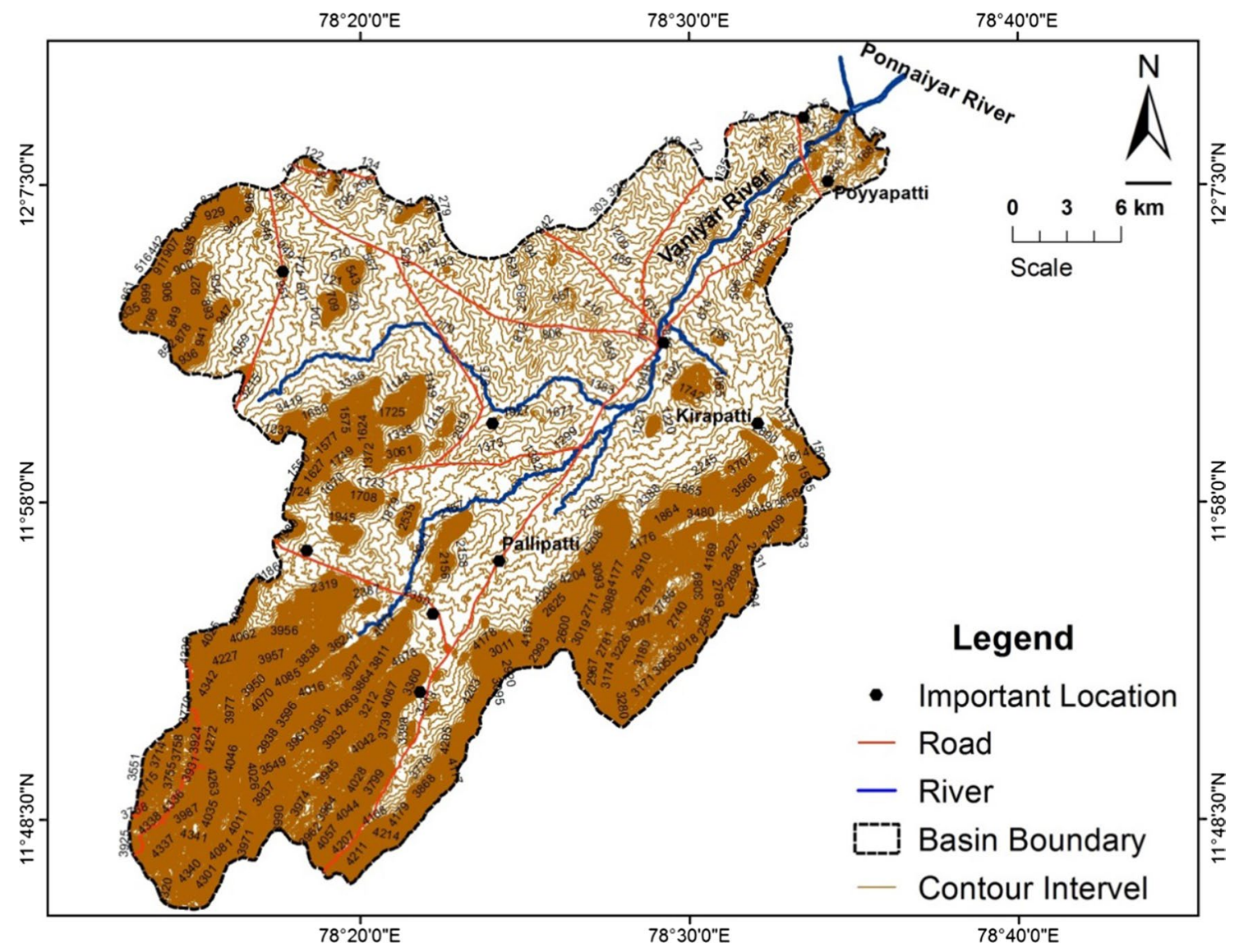

Fig. 9 Topographic map of the Vaniyar sub basin (Source: SRTM)

Table 5 Relief aspect of the Vaniyar sub basin

\begin{tabular}{llll}
\hline S. no. & Relief aspect & Category & Effect \\
\hline 1 & Basin relief & The low and high points distance & 302 and 1409 \\
2 & Relief Ratio & Basin relief/Basin length & 2.16 \\
3 & Ruggedness Number & Basin relief*Drainage density & 185.70 \\
\hline
\end{tabular}

of the basins suggests an excessive price of ruggedness quantity. The MW of the sub basins shows comparatively excessive ruggedness range, whereas MW indicates the excessive ruggedness number. The western side is especially dissected because the excessive ruggedness ranges better drainage frequency (DF) by excessive rier channel dissection and gradient lead erosion. The excellent to very exceptional drainage texture with the high remedy and relatively steep slopes results in improvement of excessive drainage density through the area well-known shows much less rainfall. The lineament density (LD) and drainage density (DD) show that replicate an effect on of structural disturbance.

\section{Aspect and altitude map}

The aspect map delineates an essential parameter to comprehend the effect of the sun on the nearby atmosphere of the range of the course to which a mountain incline faces. For the most part westbound gradient demonstrates the most blazing time of day toward the evening and as a rule, a west side fronting to be hotter than a shielded east-bound slope. Those delineate after DEM (SRTM) plainly demonstrates that north-south inclines, for the most part, happen in the pappiredipatti watershed (Fig. 10).

In this way, these slopes are high moisture content (Kombur location) as well as high vegetation albeit certain part 


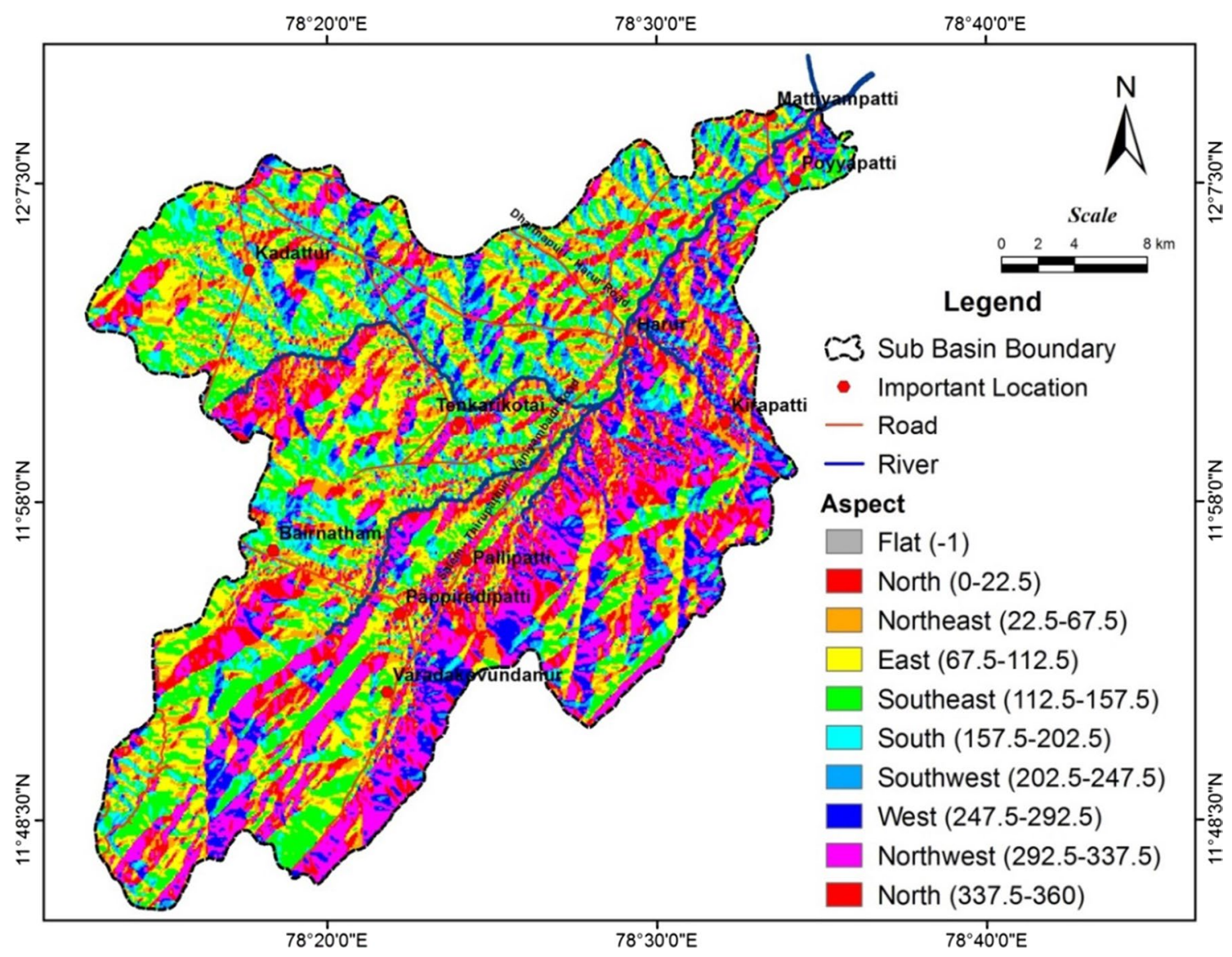

Fig. 10 Spatial variation of Aspect map delineate from DEM (SRTM)

are decreasing towards east-bound which have brought a high evaporation rate and lower moisture content. The high altitude areas are located in hill top at yercaud $1575 \mathrm{~m}$ and low altitude area located in the lower basin of mattyampatti shown in Fig. 11.

\section{Lemniscate method}

The higher value of 2.54 at pappiredipatti watershed is the more elongated shape. It is considered drainage basin development. The pappiredipatti watershed is more circular with the advancement of stages of the cycle of erosion compared to other watershed. Topography and structures play a vital role in determining the basin shape between parallel hill ranges. Figures 12 and 13 showing silt deposition in the pappiredipatti watershed.

However, slightly higher bulk density values of the surface silt deposited from the location closest to the water conservation structures than the average. This is because these were sandier than the others. This can be due to the actuality that coarser sediments are deposited beforehand than bigger sediments if surplus water flow acceleration is bargain by the recharge structures.

\section{Decision making model}

Decision making model incorporates (DMM) learning based frameworks. An accurately categorical DMM is an able framework proposed to accredit leaders to accumulate, accessible abstracts from a mix of awkward information, reports, and alone learning, or affairs of activity to analyze and accouterment issues and decide.

\section{Water resource accessibility}

Surface water of explicit observations quantity of the water body is standing as a source, height of the water, Canal water discharges for irrigation, Spill over, Catchment zone of pappiredipatti watershed, and its drainage pattern of the watershed. Observations of surface and groundwater sources are rainfall Pattern (Theissen polygon and isoheytal), Climatic condition (evaporation and temperature), Land use and Land cover pattern, geology, hydrogeomorphology, groundwater prospect zone, Survey of India (SOI Toposheet), remote sensing technique, accessibility in the context of the area. In groundwater, explicit observations are the depth of the source (zone

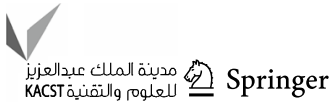




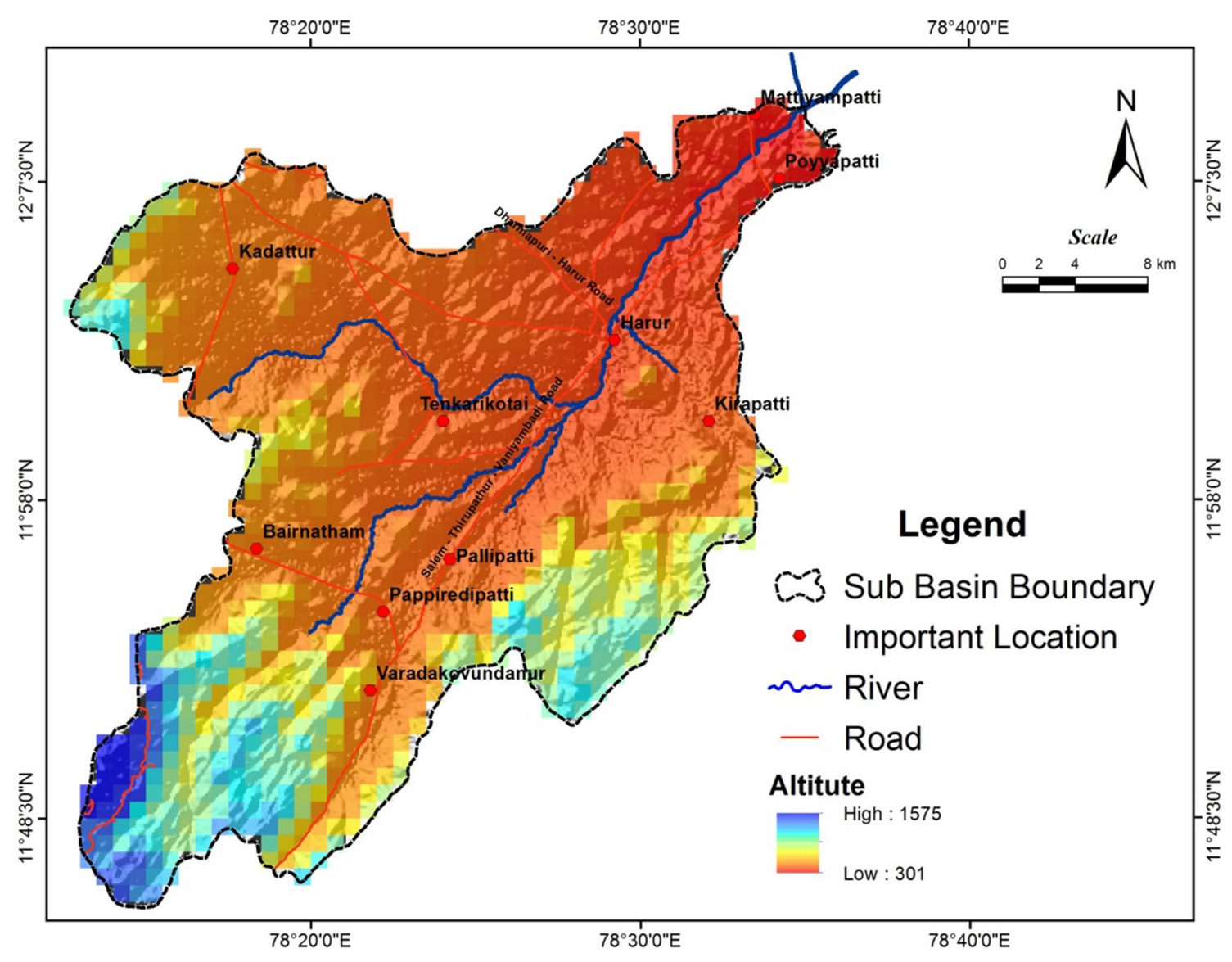

Fig. 11 Spatial variation of Interpolation of altitude map

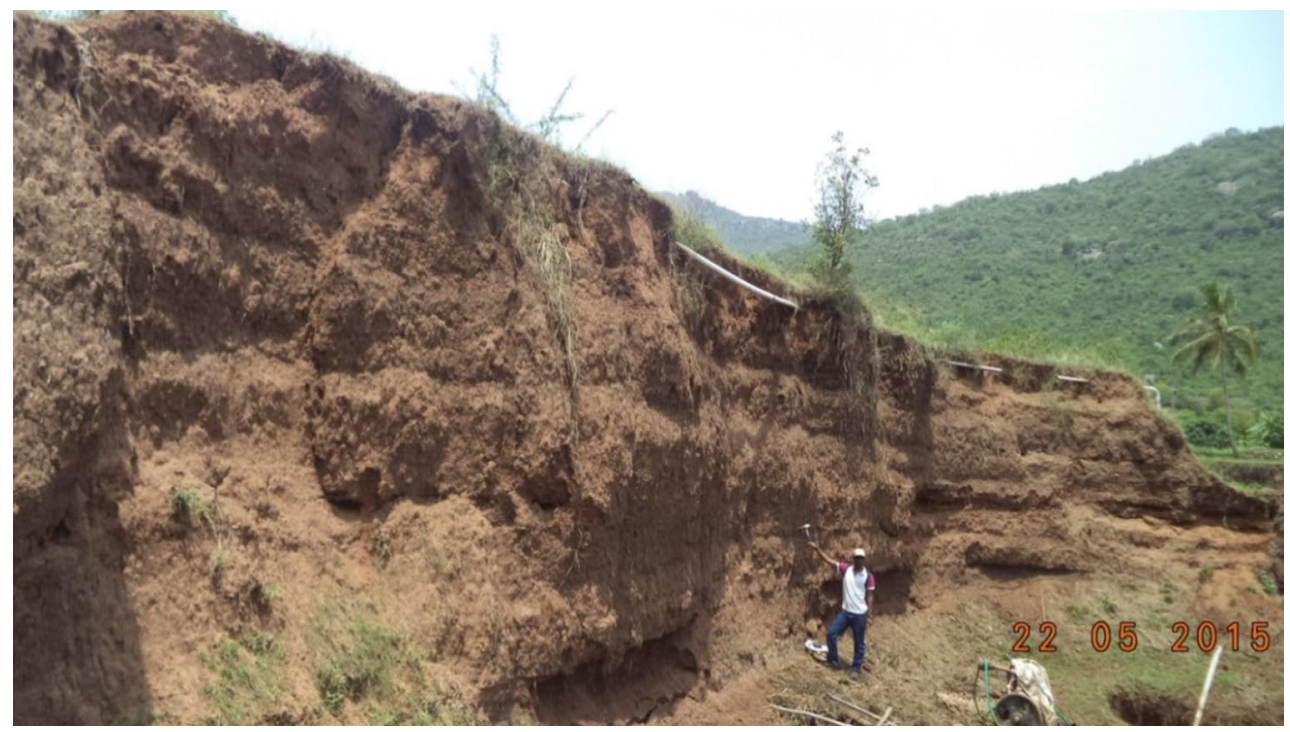

Fig. 12 Field photographs showing sediment silt (15 m) deposited at the nonanganur (2015)

of saturation), Depth of observations of groundwater sources, the variation of groundwater of level of depth and quality are essential water resource management and development. 


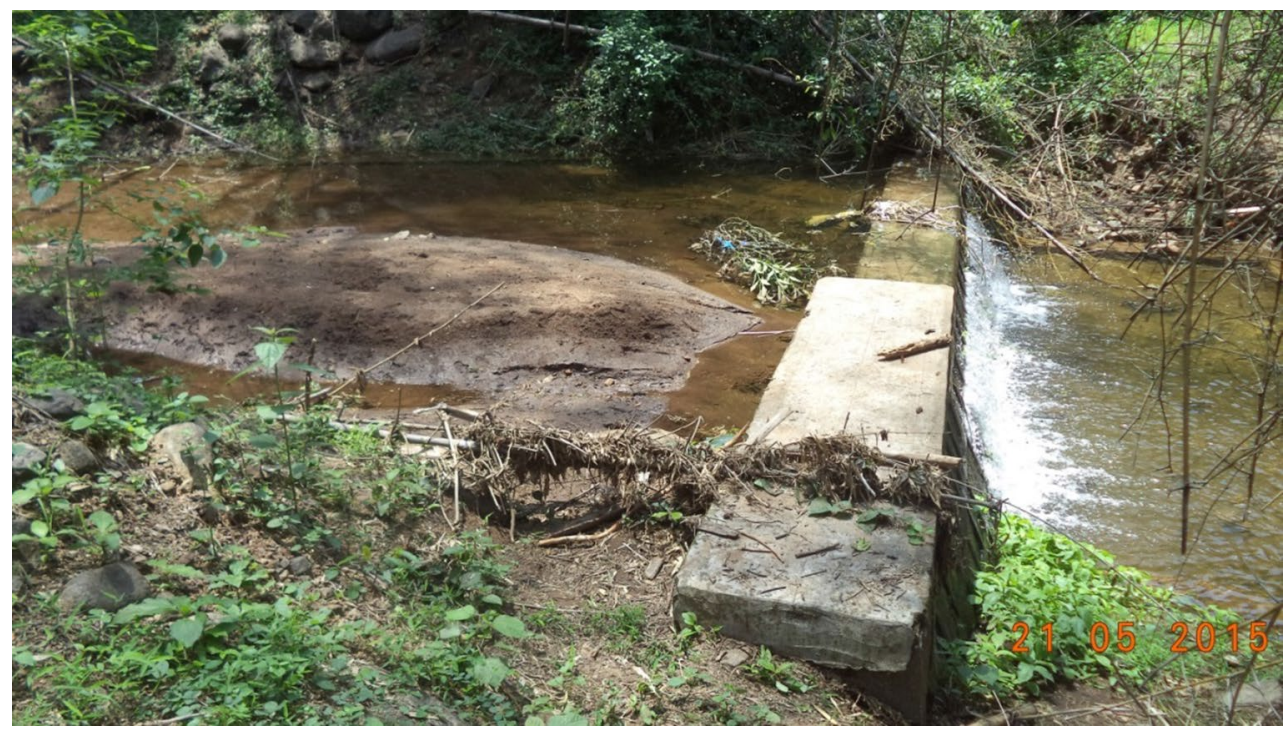

Fig. 13 Field photographs showing the Impact of a small Check Dam on Silt deposit in a non-perennial Stream at chinna manjavadi

Fig. 14 Decision support model (DSM) based on based on stream order

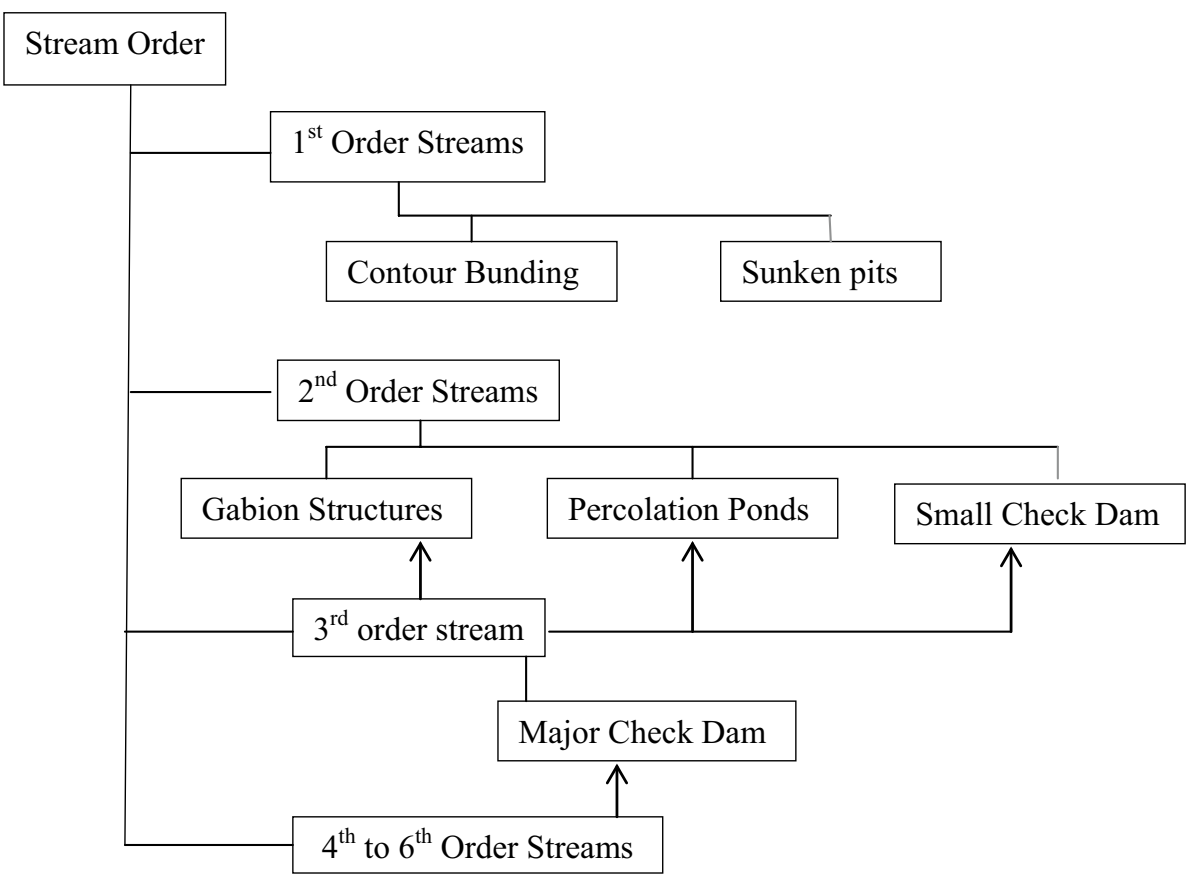

\section{Drainage pattern and stream order}

Dendritic Drainage pattern determines in this area, the direction and acceleration of the apparent run-off. It, therefore, becomes an acute agency in chief the sustainability recharge structures for an accurate site. The decision making model for alternative of acceptable structures based on the arising orders is shown in Fig. 14 which guides the acreage personnel/block to select acceptable structures based on the stream order for the site. It is to be acclaimed actualized that gabion structures and percolation tanks may be called both for 2 nd order as able-bodied as 3rd order streams. Dream order is an actual important application for an alternative selection of recharge structures as the adjustment determines the absolute breakthrough of run-off accessible for recharge/harvesting. Neglecting this arch may aftereffect in the alternative of and beneath accommodation or an overcapacity recharges structure which will either aftereffect in loss of surplus water. 


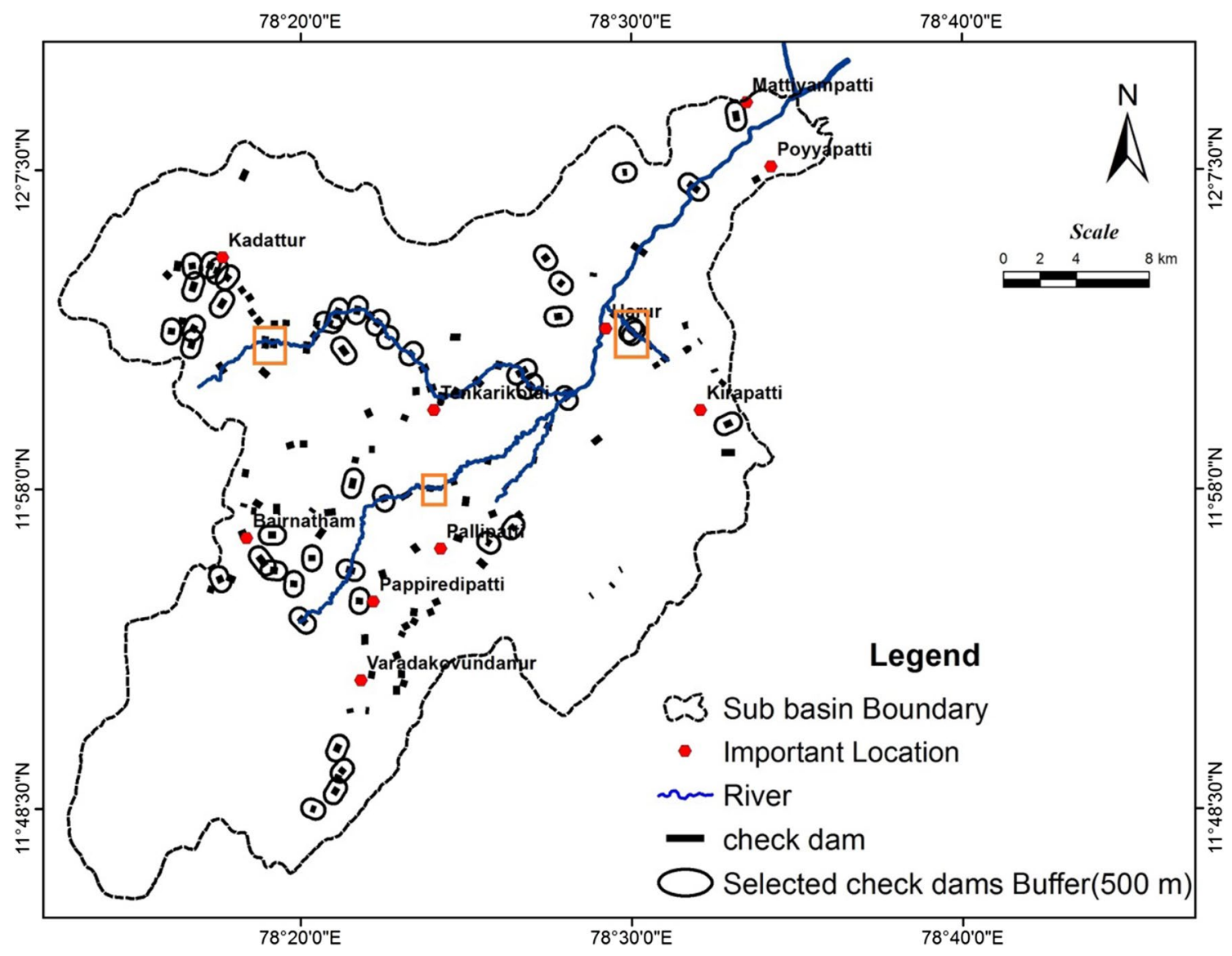

Fig. 15 Decision support model to remove unnecessary check dam

Decision support model is helpful to remove unnecessary check dam (Fig. 15) because of major check dam could be influence closer to $500 \mathrm{~m}$ in this study area. There are three check dam constructed within $500 \mathrm{~m}$. Rectangle shape demarcated area indicated the unnecessary check dam. So if remove unnecessary check dam which can reduce higher dilution when excess surplus water, increase lower sub basin recharge and reduce cost of construction material. Satheeshkumar and Venkateswaran (2018) explained about benefits of recharge structures in the sub basin.

\section{Geomorphology of the sub basin}

Geomorphology of the study area plays a basic role in free the runoff in the stream. Geomorphic condition is control on drainage order and drainage pattern depend on in the region, but the all-embracing geomorphic altitude of any arena are comprised of landforms and structural appearance which display absolute or aberrant ascendancy over the flow, accumulation, and movement of apparent and subsurface water (Fig. 16). The alternative of the sustainability structures should be in acquiescence with the geomorphic altitude, so that best advantage in agreement of subsurface water recharge or apparent water accession achieved. The assorted landforms/structural appearance that are encountered in a accustomed acreage action are piedmont apparent with shallow buried piedmont, shallow weathered on active apparent accepting shallow weathered harder rocks, Ridge type structural hills like appearance are folds \& faults, Lineaments and fractures circle in topographic low areas/valleys fills, Breadth amid beeline ridges and dykes as vertical geological barriers.

\section{Slope conditions}

The slopes of in the place show a vital role in the motion of surface and subsurface water. The determination of sustainable constructions primarily based on the slopes is showed in Fig. 17 before introducing a check dam has to the cautious investigation of the site to be attempted. The seepage area ought to be ten sections of land. The conduit ought to be on an incline of shut to half and ought to have a base profundity to the bedrock of 2 feet. Water conservation is generally, to be utilized as a phase of regular or developed channels from various experts. 
Fig. 16 Decision support model (DSM) based on Geomorphological Condition
Fig. 17 Decision support model (DSM) based on Slope conditions

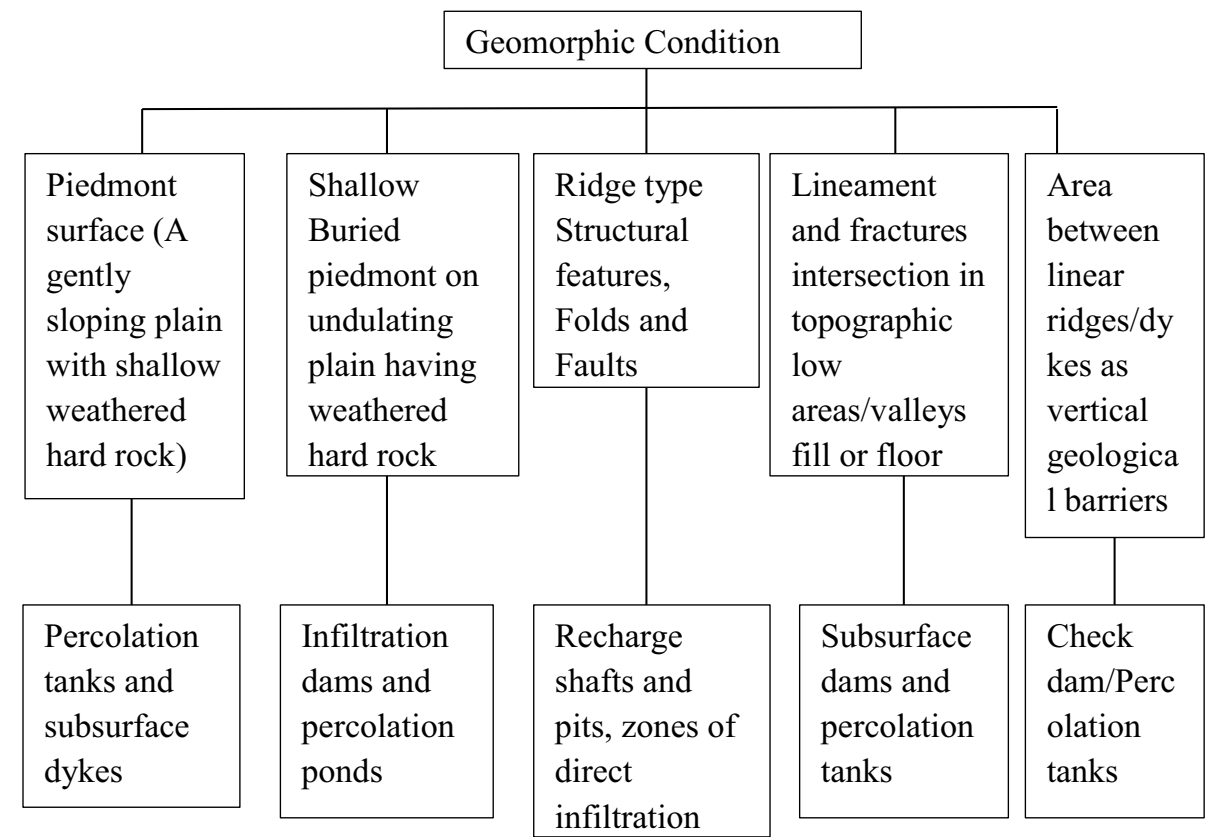

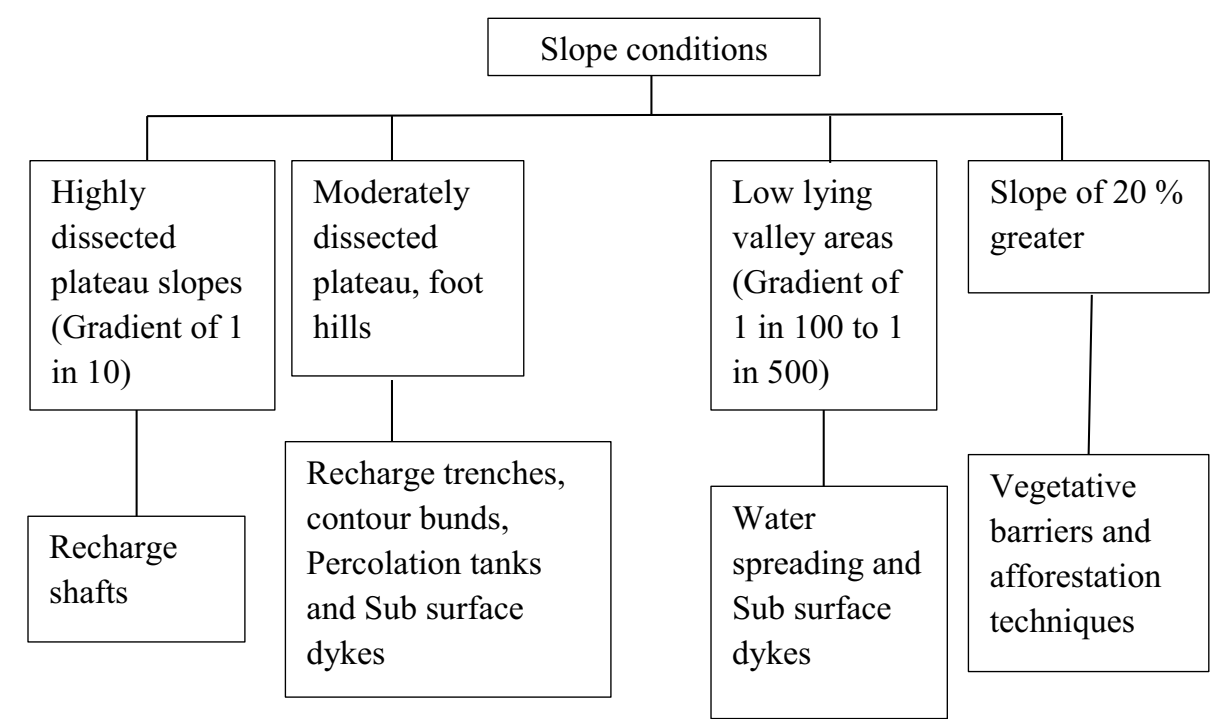

\section{Runoff of water conservation structures}

There are numerous methods, appropriately commutual and favorable to soil and water sustainable conservation, agricultural productivity and afforestation. They are adapted in areas accepting low to abstinent condensate primarily for the continuance of a monsoon season and accepting little or no ambit for about-face of water from added areas. Different measures accordant to runoff zone recharge area and acquittal division are available. The structures are about acclimated are Gabion structures, Contour bunding, Check dams and Percolation Ponds.

\section{Longitudinal profile}

The longitudinal profile can provide information about the underlying abstracts as able-bodied as perceptions into geologic processes and geomorphic of an area. The longitudinal contour of a beck approach which apparent realistically by an artifice of ambit as a action of accumbent distance (Hack 1973). Longitudinal Profile of the watershed is of a graph of distance versus elevation as shown in Figs. 18 and 19. The longitudinal profile delivers (Kumar and Pandey 1981) a clarification of the apparent as they are the erosional curves and the river advance flows 

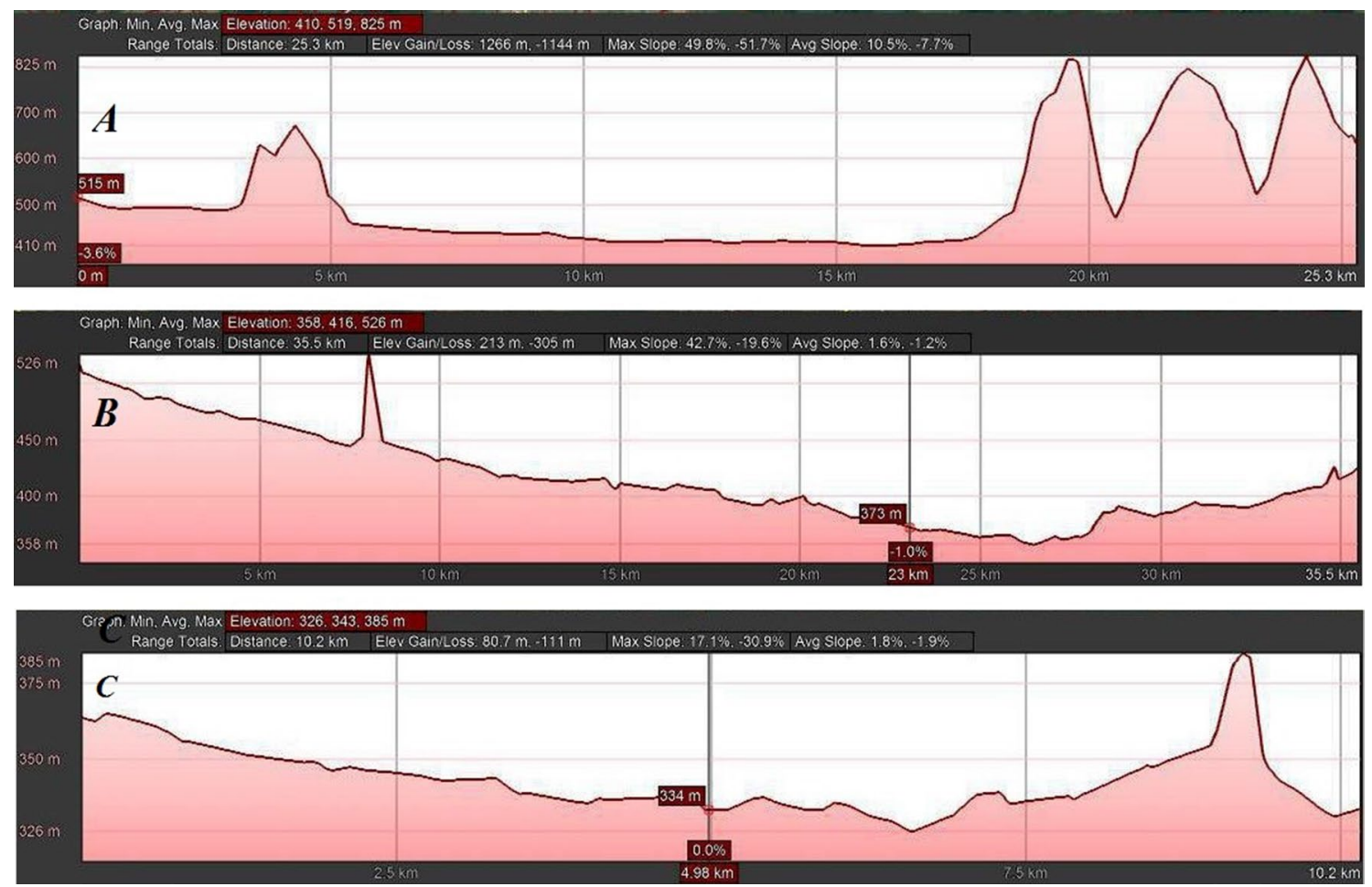

Fig. 18 Longitudinal profile of the sub basin (a east west direction, $\mathbf{b}$ and $\mathbf{c}$ EN-WS direction)

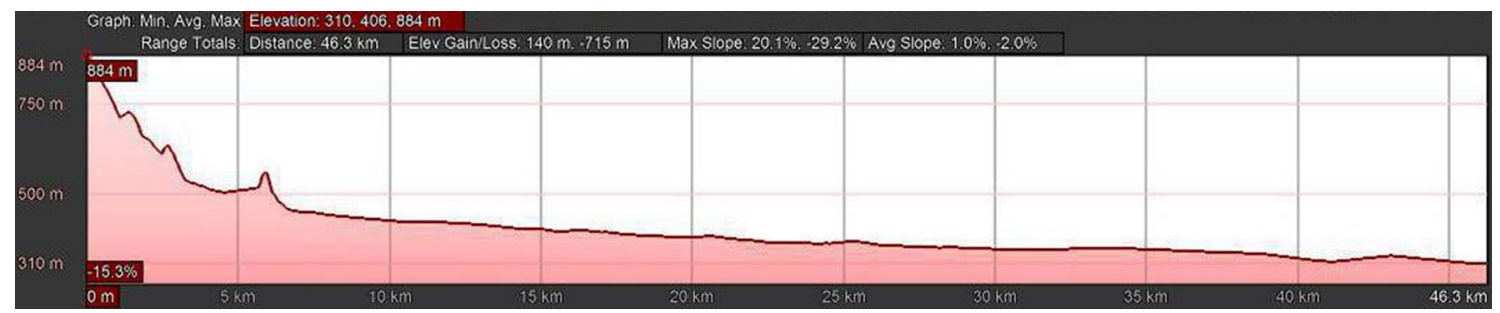

Fig. 19 Longitudinal profile of the Vaniyar River originated to end point in the sub basin of South East to North West

Table 6 Relief aspect of the Vaniyar sub basin

\begin{tabular}{lllc}
\hline Watershed & Min $(\mathrm{m})$ & Avg $(\mathrm{m})$ & Max $(\mathrm{m})$ \\
\hline PW & 396 & 531 & 1169 \\
MW & 425 & 556 & 1306 \\
KRW & 350 & 502 & 940 \\
KD2 & 354 & 437 & 831 \\
KD & 418 & 498 & 1023 \\
MOW & 302 & 327 & 346 \\
YW & 445 & 838 & 1409 \\
\hline
\end{tabular}

from the source. The streams profile is taken from Google earth as in Table 6.

The profiles are apery the structural agitation forth the stream course and the lithologic variation in the watershed.
The lineament is reflected as the slope difference along the profile. The longitudinal profile of the Vaniyar sub basin is A $(25.3 \mathrm{~km}), \mathrm{B}(35.5 \mathrm{~km}), \mathrm{C}(10.2 \mathrm{~km})$ and the average slope range $\mathrm{A}(10.5 \%), \mathrm{B}(1.6 \%)$ and $\mathrm{C}(1.8 \%)$ in the Vaniyar sub basin. The range of total distance are $\mathrm{A}$ $(3.29 \mathrm{~km}), \mathrm{B}(2.90 \mathrm{~km})$ and $\mathrm{C}(1.57 \mathrm{~km})$ Maximum slope are $\mathrm{A}(2.8 \%), \mathrm{B}(4.6 \%)$ and $\mathrm{C}(3.5 \%)$, whereas Average slope A $(1.1 \%), \mathrm{B}(0.9 \%)$ and $\mathrm{C}(1.0 \%)$ in the pappiredipatti watershed. It is observed that the distance increase from downstream and lithology have a crucial major role in the watershed whereas, in the center side that watershed medium elevation with low relief. 


\section{Conclusion}

The Vaniyar sub basin reveals the accord a part of altered aspects geomorphology and geology as a quantitative geomorphometric. The geomorphometric confirms that indicated dendritic drainage pattern, low to high surplus water and low to boundless erosion accessible. The low-slung relief, continued appearance and low circulatory specified low acquittal of apparent runoff and awfully absorbent alluvium prerequisites in the region. The ascendant abruptness is east facing, affable and moderate, advertence an about regular topography, top damp agreeable and lesser evaporation rate, therefore needs much attention. The high values of bifurcation ratios and drainage density considered that have been structural control, whereas low values considered that have been affected by a structural disturbance that also indicates dense vegetation. The form factor values that the watershed features a moderate peak flow, therefore it's most erosion and conservation must adequately for management of natural resources. A comparison of check dams with stream order is essential because impact of existing structures in that area. In addition, to understand propose new structures for water conservation and also remove unnecessary recharge structures can be manage sustainable development of groundwater and soil erosion control. The consequences of morphometric parameters acquired through toposheets analysis, google earth and ASTER data have used for mico and macro watershed sustainable development and manage within the study space. Land use/Land cowl, geological setting, surplus water and soil and morphometric parameter by the geospatial domain to recommend appropriate sites for recharge structures and soil such as Gabion structures, check dam, percolation tank, contour bunding. Finally, delineating the pappiredipatti watershed when compared to other watershed for long-term sustainable water recharge structures.

Open Access This article is distributed under the terms of the Creative Commons Attribution 4.0 International License (http://creativeco mmons.org/licenses/by/4.0/), which permits unrestricted use, distribution, and reproduction in any medium, provided you give appropriate credit to the original author(s) and the source, provide a link to the Creative Commons license, and indicate if changes were made.

\section{References}

Aryadike RNC, Phil-Eze PO (1989) Runoff response to basin parameters in southeastern Nigeria. Geogr Ann Ser A 71:75-84

Bloom AL (1979) Geomorphology. Printice-Hall of India Private Ltd., New Delhi, pp 26-89

Breilinger R, Duster H, Weingartner R (1993) Methods of catchment characterization by means of basin parameters (assisted by GIS) - empirical report from Switzerland. Report-UK Institute of Hydrology, vol 120, pp 171-181
Christopher O (2010) Hydrological analysis of onitsha north east drainage basin using geoinformatic techniques. World Appl Sci J 11(10):1297-1302

Clarke JI (1966) Morphometry from maps. In: Dury GH (ed) Essays in geomorphology. American Elsevier, New York, pp 235-274

Gottschalk LC (1964) Reservior sedimentation. In: Chow VT (ed) Hand book of applied hydrology. Section 7-1. McGraw Hill, New York

Gregory KJ, Walling DE (1973) Drainage basin. Form and process: a geomorphological approach. Edward Arnold, London

Hack JT (1960) Interpretation of erosional topography in humid temperate regions. Am J Sci 258-A:80-97

Hack JT (1973) Drainage adjustment in the Appalachians. In: Morisawa Marie (ed) Fluvial geomorphology. State University of New York, Publications in Geomorphology, Binghamton, pp 51-69

Horton RE (1932) Drainage basin characteristics. Am Geophys Union Trans 13:348-352

Horton RE (1945) Erosional development of streams and their drainage basins; hydrophysical approach to quantitative morphology. Bull Geol Soc Am 56:275-370

Jenson SK (1991) Applications of hydrologic information automatically extracted from digital elevation models. Hydrol Process 5:31-41

Jolly JP (1982) A proposed method for accurately calculating sediment yields from reservoir deposition volumes. In: Recent developments in the explanation and prediction of erosion and sediment yield. Proceedings of Exeter Symposium, July, 1982. IAHS Publication, vol 137, pp 153-161

Keller EA, Pinter N (1996) Active tectonics: earthquakes, uplift and landscapes. Prentice Hall, New Jersey

Kumar A, Pandey RN (1981) Morphometric analysis of some drainage basins of the Hazaribagh Plateau Region. National Geographical. J India 27(Part 1 and 2):50-57

Kumar B, Venkatesh M, Triphati A et al (2017) A GIS-based approach in drainage morphometric analysis of Rihand River Basin. Sustain Water Resour Manag, Central India. https://doi.org/10.1007/s4089 9-017-0118-3

Leopold LB, Wolman MG, Miller JP (1964) Fluvial processes in geomorphology. Freeman, San Francisco

Miller VC (1953) A quantitative geomorphologic study of drainage basin characteristics in the clinch mountain area, Virginia and Tennessee Columbia University, Department of Geology, Technical Report, No. 3, Contract N6 ONR 271-300

Morisawa M (1985) Rivers-forms and process. Longman group, London, pp 54-56 70-73

Nag SK, Chakraborty S (2003) Influence of rock types and structures in the development of drainage network in hard rock area. J Indian Soc Remote Sens 31(1):25-35

Nautiyal MD (1994) Morphometric analysis of a drainage basin, district Dehradun Uttar Pradesh. J Indian Soc Remote Sens 22(4):251-261

Nogami M (1995) Geomorphometric measures for digital elevation models. Z Geomorphol Suppl 101:53-67

Ogunkoya OO, Adejuwon JO, Jeje LK (1984) Runoff response to basin parameters in southwestern Nigeria. J Hydrol 72:67-84

Satheeshkumar S, Venkateswaran S (2018) Influence of groundwater recharge in Vaniyar sub-basin, South India: inference to socioeconomic benefits. Environ Dev Sustain. https://doi.org/10.1007/ s10668-018-0246-4

Scheidegger AE (1965) On the statistics of the orientation of bedding planes, grain axes, and similar sedimentological data. U.S. Geol. Survey, pp 164-167

Schumm SA (1956a) The evolution of drainage system and slopes in Badlands at Perth Amboy, New Jersey. Bull Geol Soc Am 67:214-236 
Schumm SA (1956b) Evolution of drainage systems and slopes in badlands at Perth Amboy, New Jersey. Geol Soc Am Bull 67:597-646

Shreve RL (1967) Infinite topologically random channel networks. J Geol 75:178-186

Singh S, Ojha SS (1984) Bi-variate analysis of morphometric variables of sample drainage basins of the Palamau upland, Bhihar, India. In: Mukhopadhyay SC (ed) Geographical mosaic. Calcutta University, Kolkata, pp 125-136

Smith KG (1950) Standards for grading texture of erosional topography. Am J Sci 248:655-668

Stoddart DR (1965) The shape of atolls Department of Geography, Cambridge University, Cambridge. https://doi.org/10.1016/00253227(65)90026-5

Strahler AN (1953) Hypsometric analysis of erosional topography. Bull Geol Soc Am 63:1117-1142

Strahler AN (1957) Quantitative analysis of watershed geomorphology. Trans Am Geophys Union 38:913-920

Strahler AN (1964) Quantitative geomorphology of drainage and channel networks. In: Chowl VT (ed) Handbooks of applied hydrology. McGraw-Hill, New York, pp 4-39-4-76
Strahler AN (1968) Quantitative geomorphology. In: Fairbridge RW (ed) The encyclopedia of geomorphology. Reinhold Book Crop, New York

Verstappen H (1983) The applied geomorphology, International Institute for Aerial Survey and Earth Science (ITC). Enschede, Amsterdam

Vittala SS, Govindaiah S, Honne Gowda H (2004) Morphometric analysis of sub-watersheds in the Pawagada area of Tumkur district, South India, using remote sensing and GIS techniques. J Indian Soc Remote Sens 32(4):351-362

Publisher's Note Springer Nature remains neutral with regard to jurisdictional claims in published maps and institutional affiliations. 